\title{
Haloplanus natans gen. nov., sp. nov., an extremely halophilic, gas-vacuolate archaeon isolated from Dead Sea-Red Sea water mixtures in experimental outdoor ponds
}

\author{
Rahel Elevi Bardavid, Lily Mana and Aharon Oren \\ The Institute of Life Sciences and The Moshe Shilo Minerva Center for Marine \\ Biogeochemistry, The Hebrew University of Jerusalem, 91904 Jerusalem, Israel
}

Correspondence

Aharon Oren

orena@cc.huji.ac.il

\begin{abstract}
To study biological phenomena in the Dead Sea and to simulate the effects of mixing Dead Sea water with Red Sea water, experimental mesocosms were operated at the Dead Sea Works at Sedom, Israel. Dense communities of red halophilic archaea developed in mesocosms filled with $80 \%$ Dead Sea water and $20 \%$ Red Sea water after enrichment with phosphate. The most common type of colonies isolated from these brines belonged to the genus Halorubrum. A few white-pinkish opaque colonies contained pleomorphic flat cells with gas vesicles. Three strains isolated from the latter colonies were characterized in depth. Their 16S rRNA gene sequences showed only $91 \%$ similarity to the closest cultured relative (Haloferax mediterranei), indicating that the new strains represent a novel species of a new genus. The name Haloplanus natans gen. nov., sp. nov. is proposed for this novel organism. The type strain of Haloplanus natans is RE- $101^{\top}$ $\left(=\mathrm{DSM} 17983^{\top}=\mathrm{JCM} 14081^{\top}\right)$.
\end{abstract}

The Dead Sea, located at the lowest point of the SyrianAfrican Rift Valley, is a unique, athalassohaline, salt-saturated lake with extremely high divalent cation concentrations. Its waters contain about $1.9 \mathrm{M} \mathrm{Mg}^{2+}, 1.6 \mathrm{M} \mathrm{Na}^{+}, 0.44 \mathrm{M}$ $\mathrm{Ca}^{2+}, 0.20 \mathrm{M} \mathrm{K}^{+}, 6.35 \mathrm{M} \mathrm{Cl}^{-}, 0.07 \mathrm{M} \mathrm{Br}^{-}$and $0.005 \mathrm{M}$ $\mathrm{SO}_{4}^{2-}$. The green alga Dunaliella sp. is the sole primary producer in the lake. Currently, the Dead Sea environment is too extreme to support extensive microbial life, but whenever the upper water layers become diluted by massive rain floods in winter, the algae multiply rapidly, followed by development of dense blooms of halophilic archaea: up to $1.9 \times 10^{7}$ cells ml ${ }^{-1}$ and $3.5 \times 10^{7}$ cells $\mathrm{ml}^{-1}$ were observed in 1980 and 1992, respectively. A number of novel species of the Halobacteriaceae have been isolated in the past from the lake: Haloferax volcanii, Haloarcula marismortui, Halorubrum sodomense and Halobaculum gomorrense (Oren, 1999, 2000).

In the framework of plans to construct a water conduit between the Red Sea and the Dead Sea (the 'Peace Conduit'), simulation experiments were performed on the grounds of

The GenBank/EMBL/DDBJ accession numbers for the 16S rRNA gene sequences of strains RE-101', RE-102 and RE-103 are DQ417339-DQ417341, respectively.

A phylogenetic tree based on $16 \mathrm{~S}$ rRNA gene sequences that includes environmental sequences showing a high degree of similarity to strains RE-101 ${ }^{\top}, \mathrm{RE}-102$ and RE-103 is available as supplementary material in IJSEM Online. the Dead Sea Works at Sedom, Israel, to study the effect of mixing Dead Sea water and Red Sea water. These experiments are intended to provide information on the microbiological properties of the Dead Sea when the 'Peace Conduit' plans are implemented and massive quantities of Red Sea water will enter the Dead Sea and lower the salinity of the upper water layers. Previous experiments have shown that phosphate is the limiting inorganic nutrient in the Dead Sea (Oren \& Shilo, 1985), and therefore the effect of phosphate addition was investigated as well. Experimental mesocosms $\left(0.9 \mathrm{~m}^{3}\right)$ filled with $80 \%$ Dead Sea water, $20 \%$ Red Sea water and enriched with low concentrations of phosphate became strongly red within 1-2 months as a result of dense communities of halophilic archaea (Oren et al., 2004).

We plated $0.1 \mathrm{ml}$ samples of brine from these mesocosms and of dilutions in sterile liquid medium on the following media (contents per litre): (I) $175 \mathrm{~g} \mathrm{NaCl}, 20 \mathrm{~g}$ $\mathrm{MgCl}_{2} \cdot 6 \mathrm{H}_{2} \mathrm{O}, 5 \mathrm{~g} \mathrm{~K}_{2} \mathrm{SO}_{4}, 0.1 \mathrm{~g} \mathrm{CaCl}_{2} \cdot 2 \mathrm{H}_{2} \mathrm{O}$ and $5 \mathrm{~g}$ yeast extract, $\mathrm{pH} \mathrm{7}$; and (II) $206 \mathrm{~g} \mathrm{NaCl}, 36 \mathrm{~g} \mathrm{MgSO}_{4} .7 \mathrm{H}_{2} \mathrm{O}$, $0.373 \mathrm{~g} \mathrm{KCl}, 0.5 \mathrm{~g} \mathrm{CaCl}_{2} \cdot 2 \mathrm{H}_{2} \mathrm{O}, 0.013 \mathrm{mg} \mathrm{MnCl}_{2} \cdot 4 \mathrm{H}_{2} \mathrm{O}$ and 5 g yeast extract, $\mathrm{pH}$ 7. Media were solidified with $2 \%$ agar. Most colonies ( $99 \%$ at least) that appeared after 3 weeks incubation at $37^{\circ} \mathrm{C}$ were translucent and red; preliminary $16 \mathrm{~S}$ rRNA gene sequencing indicated that these organisms were affiliated with the genus Halorubrum. In addition, a few white-pinkish opaque colonies were obtained, and these comprised pleomorphic flat cells with gas vesicles. Three 

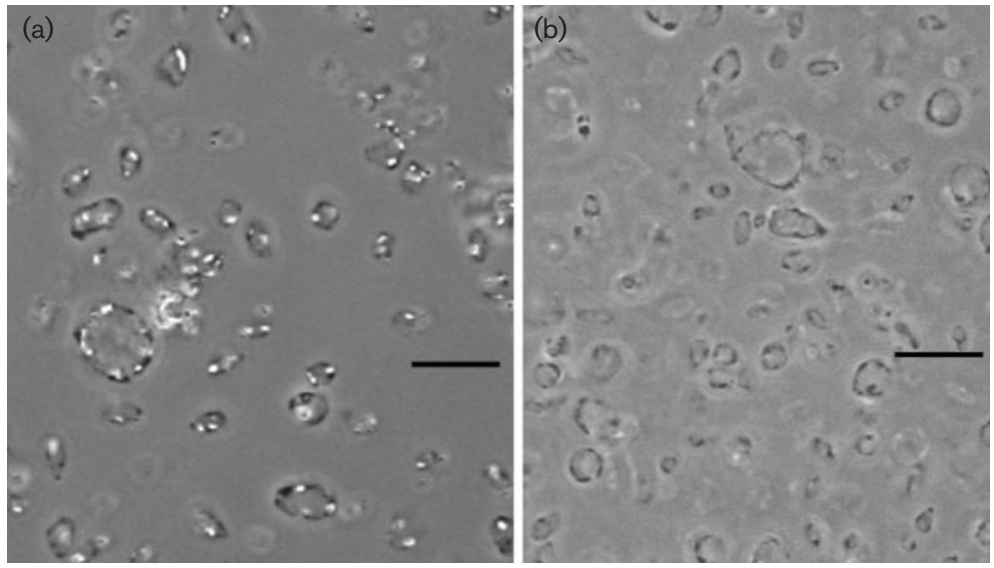

Fig. 1. Phase-contrast micrographs of gasvacuolate cells of strain $\mathrm{RE}-101^{\top}$ (a) and cells after centrifugation, causing collapse of the gas vesicles (b). Bars, $10 \mu \mathrm{m}$.

representative strains from these latter colonies were isolated, designated RE- $101^{\mathrm{T}}$, RE-102 and RE-103. Strains RE- $101^{\mathrm{T}}$ and RE-102 were grown routinely in medium (I), whereas strain RE-103 grew somewhat better in medium (II), i.e. at a slightly higher salt concentration. In view of their extremely halophilic nature, the isolates may be assumed to have been derived from the Dead Sea (340 g total dissolved salts $1^{-1}$ ) and not from the Red Sea (41 g total dissolved salts $1^{-1}$ ).

Cell morphology was examined via a Zeiss Axiovert microscope equipped with phase-contrast optics. Tests for phenotypic properties were carried out in accordance with the proposed minimal standards for the description of new taxa in the order Halobacteriales (Oren et al., 1997). Most tests were performed as outlined by Holding \& Collee (1971). Appropriate positive and negative controls were included in all tests; test organisms included, among others, the type strains of Haloferax volcanii, Haloferax mediterranei, Haloarcula marismortui, Haloarcula vallismortis, Halogeometricum borinquense and Natrialba asiatica. Growth and gas formation with nitrate as electron acceptor were tested in 15-ml stoppered bottles, completely filled with growth medium to which $\mathrm{NaNO}_{3}\left(5 \mathrm{~g} \mathrm{l}^{-1}\right)$ had been added, and containing an inverted test tube. The formation of nitrite was monitored colorimetrically. Anaerobic growth in the presence of L-arginine hydrochloride $\left(5 \mathrm{~g} \mathrm{l}^{-1}\right)$ was tested in completely filled $15-\mathrm{ml}$ stoppered tubes. Controls without arginine were included, and incubations were performed in the dark; Halobacterium salinarum R1 (=DSM 671) served as the positive control. Hydrolysis of starch was examined on agar plates supplemented with $2 \mathrm{~g}$ soluble starch $\mathrm{l}^{-1}$. Starch hydrolysis was detected by flooding the plates with iodine solution. Gelatin hydrolysis was determined by growing colonies on agar plates amended with $0.1 \%$ gelatin and flooding the plates with a solution of $15 \%$ (w/v) $\mathrm{HgCl}_{2}$ in $20 \%(\mathrm{w} / \mathrm{v}) \mathrm{HCl}$ after growth was established. Hydrolysis of Tween 20 was tested as outlined by Gutiérrez \& González (1972). Starch, gelatin and Tween 20 were each added at a concentration of $1 \mathrm{ml} \mathrm{l}^{-1}$ to autoclaved medium supplemented with $1 \mathrm{~g} \mathrm{CaCl}_{2} \cdot 2 \mathrm{H}_{2} \mathrm{O} \mathrm{l}^{-1}$. Indole production was detected with Kovacs' reagent after having grown the cells in media supplemented with $0.1 \mathrm{~g}$ L-tryptophan $\mathrm{l}^{-1}$. To test for growth on single carbon sources, yeast extract was omitted from the medium and the compound to be tested was added at a concentration of $5 \mathrm{~g} \mathrm{l}^{-1}$, together with $1 \mathrm{~g} \mathrm{NH}_{4} \mathrm{Cl} \mathrm{l}^{-1}$ and $1.36 \mathrm{~g} \mathrm{KH}_{2} \mathrm{PO}_{4} \mathrm{l}^{-1}$.

Cells grown in liquid culture $\left(2\right.$ weeks with shaking at $37^{\circ} \mathrm{C}$ ) were flat, extremely pleomorphic, $2.5-8 \mu \mathrm{m}$ in size and contained numerous gas vesicles (Fig. 1). Colonies were light pink in colour due to the presence of bacterioruberin pigments. The three new strains were extremely halophilic; optimum growth was observed at $3 \mathrm{M} \mathrm{NaCl}$ (range for growth 2.6-4.3 M), at $\mathrm{pH} 7.0$ (range $\mathrm{pH}$ 6.5-8.0) and at about $40{ }^{\circ} \mathrm{C}$ (range $37-52^{\circ} \mathrm{C}$ ). All three strains were catalaseand oxidase-positive. Gelatin, starch and Tween 20 were not hydrolysed. They were able to reduce nitrate to nitrite. Anaerobic growth on nitrate and L-arginine was not observed. Acid was not produced from glucose, fructose, sucrose or maltose. The strains differed in indole production and in the range of single carbon sources supporting growth. The phenotypic properties of the three strains are given in the species description below, and properties for which the three isolates differed are shown in Table 1.

Table 1. Differential characteristics of strains RE- $101^{\top}$, RE-102 and RE-103

\begin{tabular}{|lccc|}
\hline Characteristic & RE-101 & RE-102 & RE-103 \\
\hline Formation of indole & + & + & - \\
Growth on single carbon sources: & & & \\
Sucrose & - & + & + \\
Succinate & - & + & + \\
Glycerol & - & + & + \\
Glutamate & - & + & + \\
Maltose & - & + & + \\
Galactose & - & + & + \\
\hline
\end{tabular}


Polar lipids were extracted and analysed according to Oren et al. (1996). One- and two-dimensional TLC of the polar lipid fraction revealed that all three strains contained diphytanyl derivatives of phosphatidylglycerol, phosphatidylglycerol phosphate methyl ester, phosphatidyl glycerol sulfate and one major glycolipid chromatographically identical to S-DGD-1 previously reported for members of the genus Haloferax.

For determination of the DNA base composition and DNA-DNA hybridization experiments, genomic DNA was extracted according to Cashion et al. (1977). The DNA $\mathrm{G}+\mathrm{C}$ content was determined by HPLC of deoxyribonucleosides (Mesbah et al., 1989; Tamaoka \& Komagata, 1984). The DNA G + C content of strains RE- $101^{\mathrm{T}}$, RE-102 and RE-103 was 66.2, 66.4 and 66.1 mol\%, respectively. DNADNA hybridization analyses were performed according to the renaturation method of De Ley et al. (1970) as modified by Huß et al. (1983). Mean levels of DNA-DNA relatedness, based on duplicate assays in $2 \times$ SSC plus $10 \%$ formamide at $69^{\circ} \mathrm{C}$, were as follows: between strain $\mathrm{RE}-101^{\mathrm{T}}$ and RE-102, 78.1 $\pm 0.5 \%$; RE- $101^{\mathrm{T}}$ and RE-103, 81.1 $\pm 2.5 \%$; and RE-102 and RE-103, 93.4 $\pm 2.3 \%$. For amplification of the 16S rRNA gene, genomic DNA was extracted by using EZ-DNA-Genomic DNA isolation reagent (Biological Industries). The $16 \mathrm{~S}$ rRNA gene was amplified via PCR by using primers 21F and 1492R (Martinez-Murcia et al., 1995) and 107F and 934R (Whitehead \& Cotta, 1999; Baker et al., 2003). Sequencing was performed in the PCR by using the Big Dye Terminator reagent and the purified PCR products were electrophoresed on an ABI 373A DNA sequencer.

The almost-complete 16S rRNA gene sequences (1398$1400 \mathrm{bp}$ ) of the three new strains were determined and compared with sequences of members of the family Halobacteriaceae. A neighbour-joining phylogenetic tree (Saitou $\&$ Nei, 1987) was constructed with the MEGA package version 3.1 (Kumar et al., 2004) according to the Jukes-Cantor algorithm, and the robustness of the phylogeny was tested by bootstrap analysis (Jukes \& Cantor, 1969) after multiple alignment of data by using CLUSTAL W version 1.8 (Thompson et al., 1994). The three strains showed high levels of $16 \mathrm{~S}$ rRNA gene sequence similarity to each other:
$98 \%$ between strain RE- $101^{\mathrm{T}}$ and RE-102, $97 \%$ between strain RE- $101^{\mathrm{T}}$ and RE-103 and $99 \%$ between strain RE-102 and RE-103. 16S rRNA gene sequence similarity to other members of the family Halobacteriaceae was low. The closest related recognized species were representatives of the genera Haloferax and Halorubrum (about $91 \%$ similarity) and Halogeometricum (about 89\%) (Fig. 2). The GenBank database contained two sequences of more closely related (about $96 \%$ similarity), yet uncultured halophilic archaea: the first (GenBank accession no. DQ432015) was recovered from an oilfield at an undisclosed location and the second (GenBank accession no. DQ103676) originated from a gypsum crust in a saltern (200 $\mathrm{g} \mathrm{l}^{-1}$ total salt concentration) in Eilat, Israel, near the coast of the Gulf of Aqaba, Red Sea (Sørensen et al., 2005). A phylogenetic tree including these environmental sequences is available as Supplementary Fig. S1 in IJSEM Online. The finding of a related environmental sequence near the Red Sea coast is intriguing in view of the fact that the experimental mesocosms from which isolates RE- $101^{\mathrm{T}}$, RE-102 and RE-103 were obtained contained $20 \%$ Red Sea water sampled in Eilat. Given the high salt requirement of these organisms, it is not probable that they can live and multiply in seawater containing only $40 \mathrm{~g}$ total salts $1^{-1}$. However, it is interesting to note that closely related environmental 16S rRNA gene sequences belonging to halophilic archaea have been recovered from geographically close locations.

In view of the unusual morphological properties of the new isolates and the low levels of $16 \mathrm{~S}$ rRNA gene sequence similarity with other genera within the family Halobacteriaceae, we suggest that these three isolates represent a novel species of a new genus, for which the name Haloplanus natans gen. nov., sp. nov. is proposed.

\section{Description of Haloplanus gen. nov.}

Haloplanus (Ha.lo.pla'nus. Gr. n. hals, halos salt; L. adj. planus flat; N.L. masc. n. Haloplanus flat salt-life form).

Cells are pleomorphic, flat and contain gas vesicles. In static liquid culture the cells float to the surface. Gram-negative. Strictly aerobic. Extremely halophilic. Oxidase- and catalase-positive. The genomic DNA $\mathrm{G}+\mathrm{C}$ content is

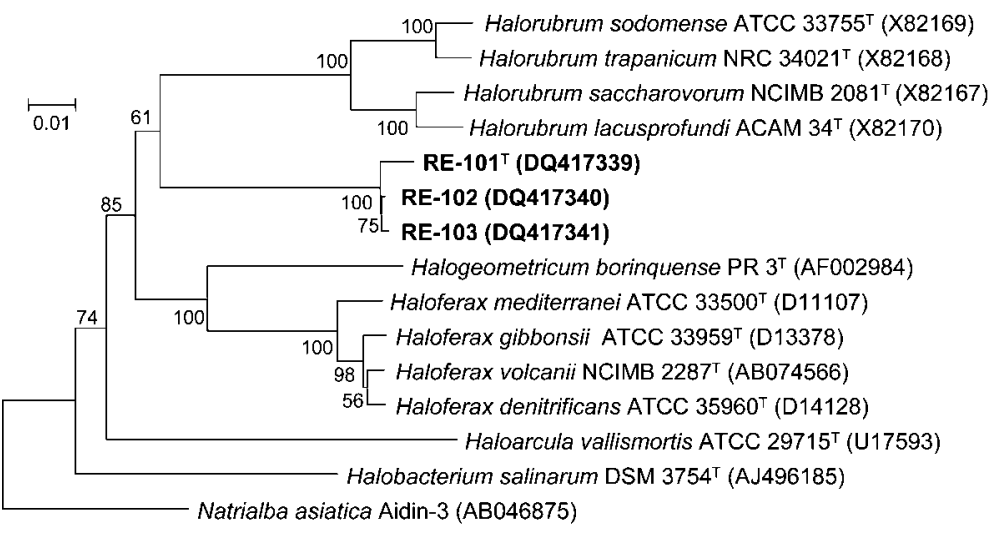

Fig. 2. $16 \mathrm{~S}$ rRNA gene sequence-based phylogeny reconstructed from distance values by using the neighbour-joining method. Bootstrap values $(>50 \%)$ are given at nodes. Natrialba asiatica Aidin-3 served as the outgroup. Bar, 0.01 inferred substitutions per nucleotide position. 
66.1-66.4 mol\% (as determined by HPLC). The type species is Haloplanus natans. Recommended three-letter abbreviation: Hpn.

\section{Description of Haloplanus natans sp. nov.}

Haloplanus natans (na'tans. L. part. adj. natans swimming, floating).

Cells are $2.5-8 \mu \mathrm{m}$ in size. Colonies are about $2 \mathrm{~mm}$ in diameter after 3 weeks incubation at $37^{\circ} \mathrm{C}$ on $2 \%$ agar plates containing $17.5-20 \%$ salt; they are translucent, entire, smooth, opaque and pinkish. Growth occurs at 2.6-4.3 M $\mathrm{NaCl}$ (optimum at $3 \mathrm{M} \mathrm{NaCl}$ ), at $\mathrm{pH}$ 6.5-8.0 (optimum at $\mathrm{pH}$ 7.0) and at $37-52^{\circ} \mathrm{C}$ (optimum at $40{ }^{\circ} \mathrm{C}$ ). Chemoorganotrophic. Gelatin, starch and Tween 20 are not hydrolysed. Reduces nitrate to nitrite. No anaerobic growth on nitrate. Does not grow anaerobically in the presence of L-arginine. Some strains produce indole from tryptophan. Glucose, ribose and acetate support growth as single carbon and energy sources. Galactose, sucrose, succinate, glycerol, glutamate and maltose are not used. No acid is produced from sugars. The polar lipids are diphytanyl diether derivatives of phosphatidylglycerol, phosphatidylglycerol phosphate methyl ester, phosphatidyl glycerol sulfate and one major glycolipid that is chromatographically identical to S-DGD-1. Poly- $\beta$-hydroxybutyrate is not produced. Resistant to ampicillin, penicillin G, chloramphenicol, rifampicin and neomycin; sensitive to bacitracin, anisomycin and novobiocin.

The type strain, RE- $101^{\mathrm{T}}\left(=\mathrm{DSM} 17983^{\mathrm{T}}=\mathrm{JCM} 14081^{\mathrm{T}}\right)$, was isolated from an experimental mesocosm filled with a mixture of water from the Dead Sea and the Red Sea, Israel. Strains RE-102 (=DSM 17984) and RE-103 (=DSM 17985) are additional strains of this species.

\section{Acknowledgements}

We thank the Dead Sea Works, Ltd, for setting up and maintaining the experimental mesocosms at Sedom. This study was supported by the Israel Science Foundation (grant no. 504/03). Financial support from the Bridging the Rift Foundation for our microbiological studies of the Dead Sea is also acknowledged.

\section{References}

Baker, G. C., Smith, J. J. \& Cowan, D. A. (2003). Review and reanalysis of domain-specific $16 \mathrm{~S}$ primers. J Microbiol Methods 55, 541-555.

Cashion, P., Holder-Franklin, M. A., McCully, J. \& Franklin, M. (1977). A rapid method for the base ratio determination of bacterial DNA. Anal Biochem 81, 461-466.
De Ley, J., Cattoir, H. \& Reynaerts, A. (1970). The quantitative measurement of DNA hybridization from renaturation rates. Eur $J$ Biochem 12, 133-142.

Gutiérrez, C. \& González, C. (1972). Method for simultaneous detection of proteinase and esterase activities in extremely halophilic bacteria. Appl Microbiol 24, 516-517.

Holding, A. J. \& Collee, J. G. (1971). Routine biochemical tests. Methods Microbiol 6A, 2-32.

Huß, V. A. R., Festl, H. \& Schleifer, K. H. (1983). Studies on the spectrophotometric determination of DNA hybridization from renaturation rates. Syst Appl Microbiol 4, 184-192.

Jukes, T. H. \& Cantor, C. R. (1969). Evolution of protein molecules. In Mammalian Protein Metabolism, pp. 21-132. Edited by H. N. Munro. New York: Academic Press.

Kumar, S., Tamura, K. \& Nei, M. (2004). MEGA3: integrated software for molecular evolutionary genetics analysis and sequence alignment. Brief Bioinform 5, 150-163.

Martinez-Murcia, A. J., Acinas, S. G. \& Rodriguez-Valera, F. (1995). Evaluation of prokaryotic diversity by restriction digestion of $16 \mathrm{~S}$ rDNA directly amplified from hypersaline environments. FEMS Microbiol Ecol 17, 247-256.

Mesbah, M., Premachandran, U. \& Whitman, W. B. (1989). Precise measurement of the $\mathrm{G}+\mathrm{C}$ content of deoxyribonucleic acid by highperformance liquid chromatography. Int J Syst Bacteriol 39, 159-167.

Oren, A. (1999). Microbiological studies in the Dead Sea: future challenges toward the understanding of life at the limit of salt concentrations. Hydrobiologia 405, 1-9.

Oren, A. (2000). Biological processes in the Dead Sea as influenced by short-term and long-term salinity changes. Arch Hydrobiol Spec Issues Adv Limnol 55, 531-542.

Oren, A. \& Shilo, M. (1985). Factors determining the development of algal and bacterial blooms in the Dead Sea: a study of simulation experiments in outdoor ponds. FEMS Microbiol Ecol 31, 229-237.

Oren, A., Duker, S. \& Ritter, S. (1996). The polar lipid composition of Walsby's square bacterium. FEMS Microbiol Lett 138, 135-140.

Oren, A., Ventosa, A. \& Grant, W. D. (1997). Proposed minimal standards for description of new taxa in the order Halobacteriales. Int J Syst Bacteriol 47, 233-238.

Oren, A., Gavrieli, I., Gavrieli, J., Kohen, M., Lati, J. \& Aharoni, M. (2004). Biological effects of dilution of Dead Sea brine with seawater: implications for the planning of the Red Sea-Dead Sea "Peace Conduit". J Mar Syst 46, 121-131.

Saitou, N. \& Nei, M. (1987). The neighbor-joining method: a new method for reconstructing phylogenetic trees. Mol Biol Evol 4, 406-425.

Sørensen, K. B., Canfield, D. E., Teske, A. P. \& Oren, A. (2005). Community composition of a hypersaline endoevaporitic microbial mat. Appl Environ Microbiol 71, 7352-7365.

Tamaoka, J. \& Komagata, K. (1984). Determination of DNA base composition by reversed-phase high-performance liquid chromatography. FEMS Microbiol Lett 25, 125-128.

Thompson, J. D., Higgins, D. G. \& Gibson, T. J. (1994). CLUSTAL W: improving the sensitivity of progressive multiple sequence alignments through sequence weighing, position-specific gap penalties and weight matrix choice. Nucleic Acids Res 22, 4673-4680.

Whitehead, T. R. \& Cotta, M. A. (1999). Phylogenetic diversity of methanogenic Archaea in swine waste storage pits. FEMS Microbiol Lett 179, 223-226. 